\title{
Mladen Havelka
}

\section{ZDRAVSTVENA PSIHOLOGIJA U HRVATSKOJ - DOPRINOS POVIJESTI RAZVOJA HRVATSKE PSIHOLOGIJE}

\author{
DOI $10.17234 / 9789531757782.16$
}

\section{Zdravstvena psihologija u svijetu}

Iako spoznaje o povezanosti psihičkih procesa i tjelesnog zdravlja postoje već tisućama godina, sve do kasnih 1970-ih godina nije postojalo posebno znanstveno područje unutar kojega bi se sustavno proučavala povezanost psihičkih procesa i tjelesnog zdravlja. Jedan od razloga za to je svakako i činjenica da, prije otprilike stoljeća i pol, nije postojala ni sama psihologija kao samostalna znanost. Međutim, i nakon osamostaljenja psihologije nakon 1879. godine, tjelesno zdravlje i tjelesne bolesti kao predmeti psihologijskih istraživanja i dalje su ostali na marginama zanimanja psihologije i psihologa. Osobito nakon što su rana istraživanja na području psihofiziologije prestala biti središnji interes nove psihološke znanosti. Razvojem novih područja psihologije -- eksperimentalne, industrijske, kliničke, razvojne, socijalne i drugih -- psihološki vidovi tjelesnih bolesti ostaju sadržajno uronjeni u razna područja psihologije, najviše u kliničku psihologiju, a bez vlastitog profesionalnog određenja. Zanimanje psihologa za probleme zdravlja, tako godinama ostaje pretežito usmjereno na probleme mentalnog zdravlja.

Prve naznake sustavnijeg interesa psihologa za psihološke vidove tjelesnog zdravlja i tjelesnih bolesti pojavljuju se usporedno s jačanjem kritika tradicionalnog, biomedicinskog modela zdravlja i bolesti, modela koji je bio vrlo učinkovit u suzbijanju masovnih zaraznih bolesti, ali postao slabije učinkovit u suzbijanju novih masovnih nezaraznih kroničnih bolesti. Usmjeren gotovo isključivo na organske vidove bolesti, biomedicinski model nije uspijevao riješiti sve veće izazove vezane uz masovnost nezaraznih kroničnih bolesti. Uz sve manju učinkovitost, suvremena je medicina ujedno i postojala sve skuplja. Nagli porast kroničnih bolesti srca i krvnih žila i drugih kroničnih bolesti, posebno narasli troškovi njihova liječenja, potaknuli su nosioce političkog odlučivanja u razvijenim zemljama, na financiranje istraživanja čiji je glavni cilj bio utvrditi najvažnije rizične 
čimbenike nastanka kroničnih bolesti, kao i načine njihove uspješne prevencije. Prva sustavna istraživanja na velikim uzorcima ispitanika vrlo brzo su pokazala da su među najvažnijim čimbenicima rizika za nastanak kroničnih nezaraznih bolesti nalaze čimbenici rizičnog ponašanja - dakle upravo oni na koje se najučinkovitije može djelovati dobrim poznavanjem psiholoških zakonitosti. U SAD-u 1960-ih godina, inicijativom predsjednika Johna F. Kennedya, započinje širok program epidemioloških istraživanja od kojih su najpoznatija istraživanja u Alamedi (Berkman i Breslow, 1983) i istraživanja u Framinghamu (Haynes, Wang, DaMota i Gomes, 1987). Rezultati su nedvojbeno ukazali na značajnu povezanost između kroničnih nezaraznih bolesti i rizičnih načina ponašanja kao što su pušenje, pretjerano konzumiranje alkohola, tjelesna neaktivnost, nezdrava prehrana, gojaznost, neodazivanje na kontrolne zdravstvene preglede, sklonost agresivnosti i drugi. Ove rezultate potvrđuju i istraživanja koja se $s$ istim ciljem provode u europskim zemljama, od kojih su najznačajnija istraživanje u Sjevernoj Kareliji u Finskoj (Puska, 1984.) i istraživanje pušačkih navika i njihovih posljedica na velikom slučajnom uzorku liječnika opće prakse u Velikoj Britaniji (Doll i Peto, 2004).

Spoznaje dobivene ovim i drugim istraživanjima povezanosti ponašanja i zdravlja snažan su poticaj mnogim psiholozima - koji su se do tada pretežno bavili problematikom mentalnog zdravlja - da se više usmjere na istraživanja odnosa psihičkih procesa, ponašanja i tjelesnog zdravlja. Podršku tome daje i Američko psihološko društvo koje zadužuje Williama Schofielda, autora zapaženih tekstova o ulozi psihologa u zdravstvu (Schofield, 1969), da izradi prijedlog programa veće uključenosti psihologa u zaštitu zdravlja.

Posljedica tih trendova sve je veće zapošljavanje psihologa u zdravstvu te poticanje istraživanja o mogućnostima poboljšanja zdravlja primjenom psiholoških znanja i vještina, pa u skladu s time Američko psihološko društvo 1978. godine osniva Odsjek za zdravstvenu psihologiju kao svoj 38. Odsjek. Joseph Matarazzo, prvi predsjednik Odsjeka 38, kao ciljeve novog Odsjeka navodi „unapredenje doprinosa psihologije razumijevanju zdravlja i bolesti putem bazičnih istraživanja, obrazovanja i pružanja usluga, kao i poticanjem združivanja biomedicinskih znanja o zdravlju i bolesti sa suvremenim psihološkim znanjima “. Nedugo zatim, već 1979. godine, objavljena je prva monografija pod nazivom „Health Psychology“ u uredništvu Georga Stonea, Francesa Cohena i Nency Adler (Stone, Cohen i Adler, 1979). Nakon kratkog vremena, 1982. godine, počinje i izdavanje prvog časopisa zdravstvene psihologije pod nazivom „Health psychology“ pod uredništvom Georga Stonea. Time je učinjen i prvi korak formalnog priznanja zdravstvene psihologije kao nove grane psihologije, a prema nekima i kao novog interdisciplinarnog područja znanosti i prakse.

I druge struke osim psihologa, postaju sve više zainteresirane za djelovanje ponašanja i psihičkih procesa na zdravlje, pa uglavnom liječnici, u suradnji sa 
psiholozima, sociolozima i antropolozima, 1977. godine osnivaju Društvo za bihevioralnu medicinu koje počinje izdavati časopis pod nazivom "Journal of Behavioral Medicine". Mnogi psiholozi, članovi Odsjeka za zdravstvenu psihologiju APA-e, učlanjeni su i u Društvo za bihevioralnu medicinu. Uz potporu Američkog psihološkog društva 2004. godine osniva se i Društvo za zdravstvenu psihologiju rada (Society for Occupational Health Psychology - SOHP).

Europske zemlje kasne u prosjeku desetak godina za zbivanjima oko osnivanja i razvoja zdravstvene psihologije. Nacionalna društva za zdravstvenu psihologiju prvo se osnivaju u Nizozemskoj, Velikoj Britaniji i Njemačkoj, a Europsko društvo za zdravstvenu psihologiju (EHPS) osnovano je 1986. godine na poticaj nizozemskih, engleskih i njemačkih zdravstvenih psihologa, (Suton, Baum i Johnston, 2005).

$\mathrm{Na}$ Međunarodnom kongresu primijenjene psihologije održanom u Madridu 1994. godine, osnovano je Međunarodno društvo za zdravstvenu psihologije (International Health Psychology Society) s ciljem ujedinjavanja globalnih napora u istraživanju i razumijevanju utjecaja ponašanja na nastajanje bolesti i u predviđanju i poticanju promjena zdravstvenog ponašanja. Društvo su osnovali predstavnici Međunarodne udruge za primijenjenu psihologiju (IAAP), Američkog psihološkog društva (APA), Europskog društva za zdravstvenu psihologiju (EHPS) te Japanskog, Australskog i Kanadskog društva za zdravstvenu psihologiju. Prva konferencija novog društva održana je u Montrealu 1996. godine.

Međunarodna udruga za primijenjenu psihologiju (IAAP) osnovala je 1984. godine svoj Odsjek za zdravstvenu psihologiju (Division 8), čiji je prvi predsjednik bio Stan Maes, profesor zdravstvene psihologije na Sveučilištu u Leidenu, ujedno i glavni inicijator osnivanja Evropskog društva za zdravstvenu psihologiju.

U drugim zemljama zdravstvena psihologija se najviše razvila u Kanadi, Australiji, Novom Zelandu i Japanu. U Africi najviše je razvijena u Južnoafričkoj Republici, a od zemljama Južne Amerike, u Brazilu.

\section{Zdravstvena psihologija u Hrvatskoj}

Sekcija za zdravstvenu psihologiju Hrvatskoga psihološkog društva osnovana je 1996. godine na Četvrtoj konferenciji Hrvatskoga psihološkog društva održanoj u Opatiji, a nakon stupanja na snagu Zakona o psihološkoj djelatnosti 2. travnja 2003. godine i osnivanja Hrvatske psihološke komore, 13. prosinca.2003. godine, osnovan je i Stručni razred za zdravstvenu psihologiju Hrvatske psihološke komore. Iz tih podataka moglo bi se pretpostaviti da je i u Hrvatskoj formalan postupak prihvaćanja zdravstvene psihologije u sustav hrvatske psihološke znanosti i prakse, uspješno završen. Međutim, sadržaji zdravstvene psihologija bili su još uvijek više dodatni dio obrazovanja i prakse kliničkih psihologa, a ne samostalno područje unutar psihologije. 
Ali treba krenuti od samih početaka. A oni sežu u prošlo stoljeće, u 1980. godinu, i vezani su uz načine na koje se zdravstvena psihologija započela uvoditi u sustav hrvatskog obrazovanja, a kasnije i u sustav znanosti i psihologijske prakse.

\section{Zdravstvena psihologija u hrvatskom obrazovanju}

Inicijative koje su tradicionalno poticale daljnji razvoj postojećih ili inicirale uvođenje novih nastavnih sadržaja, novih područja ili grana psihologije, uglavnom su dolazile sa Odsjeka za psihologiju Filozofskog fakulteta Sveučilišta u Zagrebu, a kasnije i sa studija psihologije u Rijeci i Zadru, Hrvatskih studija psihologije na Sveučilištu u Zagrebu, studija psihologije Sveučilišta Josipa Juraja Strossmayera u Osijeku, a od nedavno i sa studija psihologije na Hrvatskom katoličkom sveučilištu u Zagrebu.

Međutim, u slučaju zdravstvene psihologije nije bilo tako. Inicijativa za osuvremenjivanjem i proširenjem nastavnih sadržaja i uvođenjem zdravstvene psihologije kao novoga nastavnog predmeta u hrvatsko obrazovanje, krenula je iz područja zdravstvenog obrazovanja, odnosno s tadašnje Više škole za medicinske sestre i zdravstvene tehničare u Zagrebu i odvijala se gotovo isključivo u okvirima zdravstvenog obrazovanja. Prijedlog za uvođenje zdravstvene psihologije u hrvatski obrazovni sustav, pa time i u sustav hrvatske psihološke znanosti, nije nastao na temelju potrebe za proširenjem tema i sadržaja psiholoških istraživanja zdravlja i bolesti, jer je klinička psihologija osiguravala dosta širok prostor i za istraživanja na tom području, i nije nastao iz potrebe za proširenjem područja psihološke prakse u zdravstvu, jer je veći problem bio premali broj psihologa zaposlenih u zdravstvu, nego proširenje njihovih poslova. Napokon, na sveučilišnoj razini postojao je dovoljan prostor za otvaranje novih poslijediplomskih specijalističkih i magistarskih studija među kojima je studij kliničke psihologije zadovoljavao potrebe za postizavanje potrebnih kompetencija i vještina za rad psihologa u zdravstvu

Početkom 1980-ih godina u hrvatskom obrazovanju započeo je novi val obrazovnih reformi, kolokvijalno nazvan „Šuvarova reforma“. Jedan od njenih glavnih ciljeva bilo je prilagođavanje obrazovnog sustava načelima dijalektičkog materijalizma, tj. stvaranje takvog vrijednosnog sustava u odgoju i obrazovanje koji će utjecati na to da što veći broj ljudi u svom privatnom i javnom životu živi, radi i ponaša se sukladno načelima dijalektičkog materijalizma, koja su bila jasno precizirana u tadašnjem Zakonu o usmjerenom obrazovanju. Sukladno tom cilju Samoupravne zajednice usmjerenog obrazovanja, koje je osnivao Republički sekretarijat za prosvjetu, kulturu i fizičku kulturu Socijalističke Republike Hrvatske, osnivale su svoja stručna povjerenstva, odnosno programske savjete za svako područje i svaku razinu obrazovanja, pa je tako osnovan i Programski savjet usmjerenog obrazovanja u zdravstvu. Neki od psihologa zaposlenih u tada jedinoj Višoj školi za medicinske sestre i zdravstvene tehničare, postali su članovi 
tog Programskog savjeta i predložili su da se u cilju osuvremenjivanja psihološkog obrazovanja u području zdravstva, dotadašnji predmet pod nazivom Medicinska psihologija i psihijatrija, koji su u pravilu na srednjim i višim zdravstvenim školama predavali liječnici-psihijatri, zamijeni novim predmetom i novim sadržajem pod nazivom $Z$ dravstvena psihologija, kojeg trebaju predavati psiholozi, jer se radi o području psihologije, a ne psihijatrije.

Prijedlog je bio obrazložen i promjenama koje se u tom području psihologije događale u drugim zemljama, potkrijepljen i argumentima of financijskim i stručnim koristima od proširenja uloge psihologa u zdravstvu. Prijedlog je gotovo jednoglasno prihvaćen, te se od nastavne godine 1987./88. u srednjim zdravstvenim školama u Hrvatskoj, kao i na Višoj školi za medicinske sestre i zdravstvene tehničare, započinje izvoditi novi predmet pod nazivom $Z$ dravstvena psihologija (Delegatski vjesnik, 1986). Razlozi zbog kojih nije bilo gotovo nikakvih primjedbi na ovaj prijedlog vjerojatno su bili u tome što nastavni sadržaji zdravstvene psihologije, kao uostalom ni psihologije uopće, nisu smatrani dovoljno važnim za uspjeh ideoloških ciljeva obrazovne reforme. A novi nastavni program zdravstvene psihologije nije bio ni u kakvoj suprotnosti s reformskim ciljevima. $S$ druge strane, izostao je i otpor sveučilišnog sustava, jer su se predložene promjene odnosile isključivo na niže razine obrazovanja, tradicionalno nezanimljive sustavu sveučilišnog obrazovanju.

Kao opći okvir u kreiranju nastavnih sadržaja prvih programa zdravstvene psihologije u Hrvatskoj, poslužile su preporuke G. Stonea i suradnika (Adler, Cohen, \& Stone, 1979), koji su kao interes zdravstvenih psihologa isticali sljedeće teme; 1 . Odnos psihe i tijela kroz povijest; 2 . Promjene u pobolu stanovništva i potreba za jačanjem biopsihosocijalnog pristupa zdravlju i bolesti; 3. Socijalne uloge liječnika i bolesnika te važnost komunikacije u zdravstvu; 4. Teorije zdravstvenog ponašanja i prevencija tjelesnih bolesti; 5 . Povezanost stresa i nastanka tjelesnih bolesti (psihosomatika); 6. Načini sučeljavanja sa stresom kod tjelesnih bolesti; 7. Povezanost kroničnih tjelesnih bolesti, invaliditeta i psiholoških stanja (somatopsihologija); 8. Psihološki vidovi boli i psihološka terapija boli i druge.

Na mogućnost širenja nastave iz zdravstvene psihologije u druge dijelove obrazovanja, utjecale su i sasvim političke odluke. Odlukom Republičkog sekretarijata za prosvjetu, kulturu i fizičku kulturu Socijalističke Republike Hrvatske, 1984. godine ukinuta je pravna osobnost svih samostalnih viših škola u Hrvatskoj i one su priključene istovrsnim ili srodnim sveučilišnim studijima na fakultetima. Tim činom, samostalna Viša škola za medicinske sestre i zdravstvene tehničare postala je ustrojbena jedinica Medicinskog fakulteta Sveučilišta u Zagrebu, a svi nastavni programi, studenti, nastavnici, oprema i prostor, postali su dio Medicinskog fakulteta Sveučilišta u Zagrebu.

Tako je i Katedra za zdravstvenu psihologiju Više škole za medicinske sestre i zdravstvene tehničare, uz nešto otpora Katedre za psihijatriju s medicinskom 
psihologijom, postala jednom od katedri Medicinskog fakulteta Sveučilišta u Zagrebu. Zahvaljujući tome, na Medicinskom fakultetu Sveučilišta u Zagrebu ponovno su se pojavili psiholozi kao stalno zaposleni nastavnici. Doduše u početku ne u funkciji održavanja nastave za studente medicine, već angažirani samo za nastavu za stručne zdravstvene studije Više škole za medicinske sestre i tehničare. No, takvo stanje nije dugo trajalo. Godine 1991. na Medicinskom fakultetu Sveučilišta u Zagrebu započinje uvođenje izbornih kolegija na studiju medicine, u što se uključuju i psiholozi s Katedre za zdravstvenu psihologiju, u nastojanju da prošire svoju nastavnu djelatnost sa studija sestrinstva, fizioterapije, sanitarnog inženjerstva, medicinsko-laboratorijske dijagnostike i radiološke dijagnostike, i na studij medicine. Taj pokušaj završio je potpunim uspjehom i usvajanjem novoga nastavnog programa studija medicine u kojem su se, kao izborni predmeti, našli i psihološki predmeti Ličnost, zdravlje i bolest, Klinički intervju i Psihologija boli. Osim psihologa s Katedre za zdravstvenu psihologiju, u izvođenju ovih predmeta sudjelovali su i brojni nastavnici Medicinskog fakulteta s drugih katedri. Zanimanje studenata medicine za odabir ovih izbornih predmeta bio je vrlo velik, pa su ih mogli odabrati samo najbolji studenti. Nastava iz psiholoških predmeta započela je u akademskoj godini 1991./92. i trajala do akademske godine 1996./97. Naime, tada se sukladno Zakonu o znanosti i visokom obrazovanju iz 1993. godine, stručni studiji, tj. studiji koje organiziraju visoke škole i veleučilišta, ponovno odvajaju od fakulteta, odnosno sveučilišnog obrazovnog sustava, i postaju samostalni. Tako nastaje i Zdravstveno veleučilište kao samostalna ustanova visokog stručnog obrazovanja, te se i Katedra za zdravstvenu psihologiju s Medicinskog fakulteta vraća na Zdravstveno veleučilište.

A zanimanje Medicinskog fakulteta za daljnjom suradnjom s psiholozima u nastavi za studenta medicine naglo prestaje. Time i prestaje angažman nastavnika - psihologa u nastavi na studiju medicine te se zdravstvena psihologija ponovno predaje samo na stručnim zdravstvenim studijima i srednjim zdravstvenim školama. No, nagli i brzi razvoj zdravstvene psihologije u svijetu potiče prihvaćanje zdravstvene psihologije kao nastavnog predmeta na sveučilišnim studijima psihologije. Što se prvo zbiva na Odsjeku za psihologiju Filozofskog fakulteta Sveučilišta u Zagrebu, zatim na Hrvatskom studijima psihologije Sveučilišta u Zagrebu, a ubrzo zatim i na drugim studijima psihologije u Hrvatskoj, u Zadru, Rijeci, Osijeku i studiju psihologije Hrvatskoga katoličkog sveučilišta. Sadržaji zdravstvene psihologije se šire, ubrzo se uvode i novi predmeti iz specijalističkih područja zdravstvene psihologije, na Zdravstvenom veleučilištu započinju se izvoditi predmeti Psihologija boli i Komunikacije u zdravstvu, a uskoro zatim psihologija boli postaje i izborni predmet na studiju psihologije Filozofskog fakulteta u Zagrebu, a potom i izborni predmet na studiju psihologije Hrvatskih studija Sveučilišta u Zagrebu. Ovaj razvoj nastavnih predmeta iz područja zdravstvene 
psihologije nastavio se i dalje, pa zdravstveni psiholozi kreiraju i nove nastavne sadržaje za predmete pedijatrijska psihologija, psihoonkologija, psihokardiologija, psihodermatologija i drugih koji su predloženi za uvrštavanje u nastavne planove zainteresiranih studija psihologije, uglavnom kao izborni predmeti.

\section{Zdravstvena psihologija u hrvatskoj znanosti}

Budući da zanimanje za znanstvena istraživanja nije ograničeno formalnim okvirima u sustavu znanosti, već ovisi o istraživačkim mogućnostima i osobnom zanimanju pojedinih istraživača, nedovoljno jasno definirana uloga psihologa u zdravstvu ipak nikad nije priječila naše psihologe da se bave istraživanjima koja bi po tematici danas mogla biti svrstana u stožerna istraživanja u području zdravstvene psihologije. Prva takva istraživanja u Hrvatskoj započinju sredinom 1960-ih godina i provode se u Jedinici za sociomedicinska istraživanja tadašnjeg Zavoda za zdravstvenu zaštitu SR Hrvatske u Rockefellerovoj ulici broj 7. u Zagrebu. Tadašnju voditeljicu te istraživače jedinice, Mariju Krnic Novosel (1925.-2017.), s obzirom na teme istraživanja kojima se Jedinica za sociomedicinska istraživanja bavila, slobodno možemo smatrati prvim zdravstvenim psihologom u Hrvatskoj. Naime, teme i ciljevi tih istraživanja bile su dio općih nastojanja da se objasne složeni uzroci raznih oblika zdravstvenog ponašanja, a to je područje danas jedno od temeljnih područja zdravstvene psihologije.

Jedno od prvih takvih istraživanja u Hrvatskoj provođeno je krajem 1960-ih i početkom 70-ih godina pod nazivom Medunarodna komparativna studija koristenja zdravstvene službe (International Comparative Study/Medical Care Utilisation ili WHO/ICS/MCU). Istraživanje se u koordinaciji Svjetske zdravstvene organizacije provodilo u nekoliko zemalja svijeta, a financiralo ga je Državni ured za javno zdravstvo SAD-a. Hrvatska je bila jedno od istraživačkih područja. Voditelj cijelog projekta bio je socijalni psiholog Godfrey H. Hochbaum (1916.-1999.), jedan od vodećih psihologa u američkom sustavu javnog zdravstva, poznat i kao tvorac temeljne teorija zdravstvenog ponašanja - teorije zdravstvenih uvjerenja (Steckler, Kenneth, McLeroy i Holtzman, 2010). Postavke ove teorije bile su desetljećima najčešće korišten psihosocijalni pristup u objašnjavanju i predviđanju zdravstvenog ponašanja. Tako su i podaci o zdravstvenom ponašanju u korištenju zdravstvene zaštite prikupljeni ovim međunarodnim istraživanjem poslužili G. H. Hochbaumu i suradnicima za provjeru pojedinih teorijskih postavki modela zdravstvenih uvjerenja i potakle brojna daljnja istraživanja uzroka slabog odaziva stanovništva na kampanje ranog otkrivanja bolesti, slabog sudjelovanja u preventivnim zdravstvenim programima, a u kasnijem razdoblju i istraživanja razloga slabog pridržavanja zdravstvenih savjeta i uputa (Rosenstock, 1974; Becker, 1974). Osim sudjelovanja u ovom velikom istraživanju, Marija Krnic Novosel bila je i voditeljica još jednog važnog nacionalnog istraživanja na području Hrvatske pod nazivom Orijentacija 
pacijentu u općoj medicini. Istraživanje se provodilo na reprezentativnom uzorku ordinacija opće medicine s područja cijele Hrvatske sa ciljem utvrđivanja povezanosti komunikacije između liječnika i bolesnika u ordinacijama opće medicine sa zadovoljstvom bolesnika, kao i slijeđenja zdravstvenih savjeta i uputa (Novosel i Havelka 1974). Njezini suradnici kasnije su nastavili sa sličnim istraživanjima (Havelka i Barath, 1977; Havelka, 1981; Barath, Havelka, Selihar, 1987; Barath, Havelka, Gavrilo,1989; Barath, Havelka, Despot Lučanin, Bastašić (1990), i s pokušajima što većeg uključivanja sadržaja iz zdravstvene psihologije u hrvatsko srednje, više i visoko obrazovanje (Barath, 1995; Barath, Matul, Sabljak, 1996; Havelka, 1981; 1982; 1985; 1988; 1992; 1998; 2002; Havelka i Ševo, 2002; Havelka i Havelka Meštrović, 2013; Zarevski i Havelka, 2014).

I mnogi drugi hrvatski psiholozi započeli su provoditi istraživanja, objavljivati radove, knjige i kongresna priopćenja po temama bliska ili pripadajuća području zdravstvene psihologije, senzibilizirajući time stručnu i laičku javnost za psihološke vidove tjelesnog zdravlja i tjelesnih bolesti. Od mnogih za primjer navodimo neke; Arambašić, 2008; Bezić, 1990; Brkljačić i Kaliterna 2000; Galić, 2010; Gračanin, 2015; Grgurević, 2014; Grubić, 2008; Grubić, Ljubešić, Filipović Grčić, 2013; Havelka Meštrović i Čuić, 2011; Havelka Meštrović i Buhin, 2017; Hudek Knežević, 1999; Hudek Knežević i Kardum, 2000 i 2006; Ivanec, 2015; Jokić Begić i Arambašić, 2010; Jokić Begić, Žigić, Nakić Radoš, 2014; Kaliterna, 1990; Kostović Srzentić, Pukljak Iričanin, Grubić, Bogdanić, Filipović Grčić (2017); Krizmanić, Vizek Vidović, Kolesarić, Harambašić1986; Krizmanić i Kolesarić,1996; Ljubešić, 2013; Malčić, Cazin, Jelušić, Ivandić, Aberle, Grubić, 2004; Martinac Dorčić i Ljubešić, 2009; Nakić Radoš, Tadinac, Herman, 2018; Pačić Turk, 2001; Petričić i Vulić Protorić, 2009; Pibernik Okanović, Szabo, Metelko, 1998; Pokrajac Bulian i sur., 2011; Pukljak Iričanin, Perković, Petrak, Rukavina, Kostović Srzentić, 2011; Szabo, Pibernik Okanović, Metelko, 2010 ; Tadinac, 2004; Tadinac, Hromatko, Jokić Begić, Kotrulja, 2009; Vulić Prtorić i Galić, 2004; Vulić Prtorić, Galić, Coha, Grubić i sur. 2007; Zarevski i sur., 2015 i drugi.

\section{Zdravstveni psiholozi i Domovinski rat}

Domovinski rat prekinuo je razvojne planove mnogih struka, pa tako i zdravstvene psihologije. Najveću pozornost psiholozi su tijekom Domovinskog rata usmjerili na pružanje pomoći u prevladavanju psiholoških i psihosocijalnih posljedica ratnih stradanja. Tako su svi psiholozi u razdoblju od 1990.-1995. godine, a mnogi i kasnije, usmjerili sve svoje profesionalne snage na primjenu psiholoških znanja i vještina u ublažavanju psihosocijalnih posljedica ratnih razaranja. Organizirani su brojni programi psihološke i psihosocijalne pomoći žrtvama rata - posebno djeci, invalidima, prognanicima, izbjeglicama i starijim 
ljudima. Sredinom 1992. godine u Hrvatskoj je bilo oko 600000 prognanih i izbjeglih iz ratnih područja Hrvatske i Bosne i Hercegovine, kojima je bila potreban sva moguća, pa i psihološka pomoć. Zdravstveni psiholozi okupljeni oko Katedre za zdravstvenu psihologiju Više medicinske škole Medicinskog fakulteta Sveučilišta u Zagrebu, u suradnji sa medicinskom sestrama Kabineta za zdravstvenu njegu Više medicinske škole, organizirali su brojne seminare o psihološkom zbrinjavanju ljudi izloženih ratnim stradanjima. U suradnji s Hrvatskim psihološkim društvom, posebno članovima Sekcije za školsku psihologiju i dijelom psihologa s Odsjeka za psihologiju Filozofskog fakulteta Sveučilišta u Zagrebu, organizirali su tijekom 1991.-1993. godine brojne aktivnosti usmjerene ublažavanju psihosocijalnih posljedica rata, a 1993. godine osnovali i dobrotvorno udruženje „Dobrobit“, unutar kojega su proširili svoju djelatnost na ublažavanju psihosocijalnih posljedica rata na razne načine - od organizacije i provođenja savjetovališnog rada, priređivanja edukativnih video materijala i snimanja obrazovnih TV emisija, objavljivanja tiskanih obrazovnih materijala, do izravnog rada na terenu u zbjegovima prognanika i izbjeglica, bolnicama i drugim ustanovama, do provođenja obrazovnih programa osposobljavanja volontera - pomagača izbjeglicama i prognanicima u zbjegovima izbjeglica i prognanika u inozemstvu. Neko vrijeme, krajem 1991. i tijekom 1992. godine, psiholozi Katedre za zdravstvenu psihologiju Više medicinske škole Medicinskog fakulteta, bili su angažirani i u Uredu za psihosocijalnu prilagodbu prognanika i izbjeglica Vlade Republike Hrvatske, u kojem su, u suradnji s UNICEF - om i drugim humanitarnim organizacijama koje su se istovremeno bavile pružanjem psihosocijalne pomoći žrtvama rata (Havelka, 1996), organizirali nekoliko obrazovnih programa vezanih uz pružanje psihosocijalne podrške prognanim i izbjeglim obiteljima, posebno prognanoj i izbjegloj djeci.

Tijekom tih aktivnost nastali su i brojni pisani materijali o načinima prevladavanja ratnih trauma i suočavanja s psihosocijalnih posljedica rata, koji su bili od koristili kako psiholozima, liječnicima, medicinskim sestrama, socijalnim radnicima, tako i samim žrtvama rata i njihovim obiteljima (Krizmanić i sur., 1991. a i b; Krizmanić i sur., 1995.); Krizmanić, 1995); Havelka i Krizmanić, 1995; Havelka, 1998.).

Uz to, prevedeni su i strani priručnici koji su se bavili sličnom problematikom: Pomoć djeci koja žive u teškim prilikama te Komuniciranje s djecom, u suradnji s međunarodnom humanitarnom organizacijom Save the Children i Sprječavanje i suzbijanje stresa medu djelatnicima hitnih službi i Priručnik za pomoć djeci u situacijama rata u suradnji s UNICEF-om.

U suradnji s UNICEF-om i obrazovnim programom Hrvatske radiotelevizije, pod uredništvom urednice obrazovnog programa, psihologinje Višnje MasnecVodanović (u režiji Petra Krelje), snimljena je i serija od šest obrazovnih videokazeta $s$ temama vezanim uz ratne traume djece i načine njihova prevladavanja. Kazete 
su presnimljene u nekoliko stotina kopija i podijeljene po zbjegovima prognanika i izbjeglica na području Hrvatske i Bosne i Hercegovine.

Za svoje doprinose ublažavanju psihosocijalnih posljedica rata, psiholozi okupljeni oko Katedre za zdravstvenu psihologiju Više medicinske škole Medicinskog fakulteta Sveučilišta u Zagrebu, Kabineta za zdravstvenu njegu Više medicinske škole i dobrotvornog udruženja „Dobrobit“, nagrađeni su najvišim psihološkim nagradama Hrvatskog psihološkog društva, nagradom „Ramiro Bujas“ i „Zlatnim grbom" Hrvatskog psihološkog društva, a za istovremene napore na području unapređenja stručnog visokog obrazovanja u Republici Hrvatskoj, neki od njih odlikovani su i odlikovanjem „Reda Danice Hrvatske s likom Ruđera Boškovića“.

Nakon Domovinskog rata, od 1998. - do 2004. godine psiholozi Katedre za zdravstvenu psihologiju, tada već Katedre Zdravstvenog veleučilišta u Zagrebu, u suradnji s Ministarstvom rada i socijalne skrbi, organizirali su u okviru dobrotvornog udruženja „Dobrobit“, programe cjelovite skrbi za starije ljude u zajednici, razvijajući time i nove modele izvaninstitucionalne skrbi za starije građane grada Zagreba (Havelka, 2003).

\section{Zdravstvena psihologija u hrvatskom sustavu zdravstvene zaštite}

$\mathrm{Na}$ četvrtoj Konferenciji Hrvatskog psihološkog društva održanoj 1996. godine u Opatiji, utvrđeno je da uloga i status psihologa u zdravstvenoj praksi nisu sukladni mogućem doprinosu psihologije povećanju kvalitete zdravstvenih usluga, te je predloženo da se odgovornima u sustavu zdravstva upute prijedlozi proširenja psiholoških usluga u zdravstvu, tj. postojeći opisi poslova psihologa dopune novim sadržajima. Na osnovu održane rasprave načinjena je lista novih poslova u zdravstvenoj praksi koja je obuhvaćala poslove iz područja zdravstvene psihologije i to; 1. Utvrđivanje psiholoških rizičnih čimbenika koji pogubno djeluju na zdravlje; Utvrđivanje psiholoških čimbenika koji djeluju na pridržavanje zdravstvenih savjeta i uputa; 2. Uvođenje programa promjena ponašanja usmjerenih uspostavljanja zdravog načina života; 3. Razvoj i primjena psiholoških tehnika ublažavanja boli; 4. Razvoj i primjena programa suočavanja sa stresom; 5 . Poticanje razvoja i širenja samozaštitnih grupa bolesnika i članova obitelji bolesnika oboljelih od kroničnih bolesti; 6. Razvoj, uvođenje i primjena psiholoških tehnika jačanja imunosnih odgovora na bolest; 7 . Unapređenje tehnika komunikacija između zdravstvenih djelatnika i bolesnika; 8 . Sudjelovanje u interdisciplinarnim znanstvenim istraživanjima; 9. Uvođenje i razvoj programa za unapređenje kvalitete života kroničnih bolesnika, invalida i starijih osoba; 10. Razvoj i primjena tehnika sveobuhvatne rehabilitacije invalida; 11 . Razvoj i primjena tehnika dijagnosticiranja i terapije psiholoških i psihosocijalnih posljedica ratnih trauma; 12 . Provođenje psihološke pripreme prije kirurških zahvata; 13. Evaluacija uspješnosti pojedinih psiholoških tehnika u prevenciji i liječenju bolesti; 14.Razvoj i primjena tehnika 
psihološke pomoći i podrške teško oboljelim bolesnicima i njihovim obiteljima ( rak, srčanožilne bolesti, astma, AIDS); 15. Suradnja u kreiranju etičkih načela primjene medicinske tehnologije ( npr. presađivanja organa, eutanazije i dr.).

Dva su osnovna razloga zbog kojih većina ovih opisa poslova nisu ušli u standarde rada psihologa zaposlenih u zdravstvu. Prvi razlog vezan je uz obrazovanje psihologa. Bazično obrazovanje psihologa čije završavanje je uvjet za stjecanje osnovne dopusnice za rad u psihološkoj djelatnosti, nije dovoljno za stjecanje specijalističkih kompetencija u području zdravstvene psihologije, a specijalistički poslijediplomski studij kliničke psihologije na Filozofskom fakultetu Sveučilišta u Zagrebu, te studij savjetodavne psihologije na Filozofskom fakultetu Sveučilišta u Rijeci još nisu dovoljno usmjerena na problematiku zdravstvene psihologije.

Drugi razlog zašto nije zaživio širi opis poslova zdravstvenih psihologa što ga je još 1996. godine predložilo Hrvatsko psihološko društvo, treba tražiti u premještanju fokusa strukovnih psiholoških aktivnosti ka donošenju Zakona o psihološkoj djelatnosti i osnivanju Hrvatske psihološke komore, čime bi društveni status i profesionalna uloga psihologa bili bolje i čvršće regulirani. Istovremeno s održavanjem rasprava o poboljšanju i proširenju uloge psihologa u zdravstvu, krajem 1990ih godina intenzivirane su i šire rasprave među psiholozima o potrebi osnivanja psihološke komore, koja bi imala javne ovlasti pa time i pravo samostalnog reguliranja vlastite profesije, kao i uspostave čvrstih kriterija za obavljanje pojedinih poslova unutar psihološke djelatnosti. U to vrijeme zbivale su se i velike promjene u sustavu zdravstva („poluprivatizacija“ službi opće medicine i medicine rada), koje su prijetile psiholozima zaposlenima u tim sektorima zdravstva, da ostanu bez posla zbog nemogućnosti da kao „nezdravstveni“ djelatnici ravnopravno sudjeluju u procesima privatizacije. Takve prijetnje ojačale su pritisak na Hrvatsko psihološko društvo da što prije predloži Zakon o psihološkoj djelatnosti i poduzme sve potrebno da se Zakon prihvati, kako bi temeljem njega mogla biti osnovana Hrvatska psihološka komora, što bi onda otvorilo široke mogućnosti i psiholozima da mogu samostalno otvarati svoje psihološke ordinacije i na taj način imati veći prostor za rješavanje svog radnog statuse. Sve to umanjilo je pritisak na nadležne službe i povjerenstva Ministarstva zdravstva, da se unutar državnog zdravstva ostvare predložena proširenja poslova i uloge psihologa u zdravstvu.

\section{Perspektive razvoja zdravstvene psihologije u Hrvatskoj}

Osnivanjem Hrvatske psihološke komore otvorio se novi, širi prostor planiranja strateškog razvoja psihološke profesije u cjelini, pa time i zdravstvene psihologije. Perspektive razvoja psihologije u Hrvatskoj, nakon donošenja Zakona o psihološkoj djelatnosti, počele su najviše ovisiti o samim psiholozima, njihovim vizijama, angažmanu i sposobnostima da kreiraju takve strateške odluke i stvaraju 
takvo ozračje u kojem će se razvoj pojedinih područja psihologije moći ostvariti svoj maksimum.

To opće načelo vrijedi i za zdravstvenu psihologiju unutar koje bi prvo trebalo analizirati koliko su psiholozi u zdravstvu svojim stručnim i znanstvenim radom uspjeli uvjeriti zdravstvene djelatnike, prije svega liječnike, da svojim teorijskim znanjima i praktičnim vještinama mogu značajno pomoći u povećanju kvalitete i humanizaciji zdravstvene prakse. Tek nakon toga bilo bi moguće odlučiti u kojem pravcu bi trebalo nastaviti. No, i bez velikih analiza već se sada može nazrijeti da na putu šire uloge psihologa u zdravstvu postoje dva glavna problema, a oni su, prvo, nedostatno specijalistički obrazovanje psihologa iz područja zdravstvene psihologije i drugo, vrlo slabo obrazovanje liječnika iz zdravstvene psihologije.

Oba problema mogu i moraju pokušati riješiti sami psiholozi. Rješenje prvog je lakše. Ono ovisi o uskoj suradnji Hrvatske psihološke komore i studija psihologije kroz koju treba razvijati nove modele psihološkog obrazovanja koji će psiholozima u zdravstvu osigurati veće kompetencije i vještine za obavljanje šireg raspona poslova u zdravstvu i za veću suradnju sa zdravstvenim djelatnicima. Prvi koraci u ovim nastojanjima trebali bi biti; 1 . Proširenje raspona tema tečajeva trajnog obrazovanja kliničkih psihologa u organizaciji Komore većim brojem tema iz zdravstvene psihologije; 2.Obogaćivanje nastavnih programa stručnog specijalističkog poslijediplomskog studija psihologije većim brojem sadržaja i širim rasponom praktične nastave iz područja zdravstvene psihologije; .3. Razmatranje mogućnosti otvaranja sveučilišnog interdisciplinarnog doktorskog studija iz zdravstvene psihologije na Sveučilištu u Zagrebu u suradnji sa drugim studijima psihologije, Medicinskim fakultetom, Edukacijsko - rehabilitacijskim fakultetom, odsjecima za sociologiju i pedagogiju Filozofskog fakulteta, kliničkim bolnicama, i specijalističkim bolnicama, te privatnim psihološkim ordinacijama.

Suočavanje s drugim problemom je teže jer samo djelom ovisi o psiholozima, a najvećim djelom o visokoškolskim ustanovama u kojima se obrazuju zdravstveni djelatnici - medicinskim i stomatološkim fakultetima i visokim zdravstvenim školama i veleučilištima. $\mathrm{Na}$ razini visokih škola i veleučilišta zdravstvena psihologija uključena je u nastavu stručnih zdravstvenih djelatnika, posebno medicinskih sestara, radnih terapeuta i fizioterapeuta već četrdesetak godina i postoji dovoljan broj nastavnika kvalificiranih za nastavu. Na medicinskim i stomatološkim fakultetima nema ni predmeta niti nastavnika - psihologa iz područja zdravstvene psihologije. Taj problem moguće je riješiti samo jačanjem suradnje psihologa, medicinara i stomatologa kroz sudjelovanje u zajedničkoj edukaciji na svim razinama, većim obimom zajedničkog rada u praksi i većim opsegom interdisciplinarnih istraživanja. Stvaranje jačih veza između medicine i psihologije može se potaknuti formiranje pozitivnijih stavova medicinara prema psihologiji i psiholozima u proširiti uvjerenje da su mogući brojni oblici surad- 
nje na korist i zdravstvenih struka i psihologa, a prije svega u korist uspješnijeg liječenja bolesnika.

Tek nakon toga mogu se rješavati druga pitanja u pojedinim sektorima zdravstva u kojima rade psiholozi. Iako danas najviše zdravstvenih psihologa radi u bolničkim zdravstvenim ustanovama, najveće perspektive razvoja zdravstvene psihologije u budućnosti mogu se očekivati u okviru primarne zdravstvene zaštite na području očuvanja zdravlja (primarne prevencije), te ublažavanja simptoma i novih rizika kod već postojećih kroničnih bolesti (sekundarna i tercijarna prevencija). Sve veća svijest o utjecaju životnog stila na očuvanje zdravlja i sučeljavanje s bolešću doprinositi će potrebi za psiholozima i psihološkim postupcima i tehnikama usmjerenim formiranju pozitivnih i odbacivanju negativnih oblika zdravstvenog ponašanja.

U okviru bolničke zdravstvene zaštite razvoj novih tehnologija u medicini i sve veća dehumanizacija odnosa zdravstvenih djelatnika i bolesnika, i, posljedično, sve veće nezadovoljstvo bolesnika medicinskim tretmanom, nužno će dovesti do potrebe za uključivanjem psihologa u unapređenje komunikacija u zdravstvu općenito, a posebice unapređenju komunikacije i odnosa između bolesnika i zdravstvenih djelatnika. Usprkos sve djelotvornijoj dijagnostici i terapiji, standardno uvođenje psiholoških postupaka u cjelovit pristup pomoći bolesniku, pokazati će se nužnim za sveukupnu djelotvornost bolničkog liječenja.

Osim u sustavu zdravstva nove mogućnosti psihologa pojaviti će se i razvojem nevladinog sektora, tj. organizacija i udruženja civilnog društva koje će u lokalnoj zajednici razvijati novi sustav pružanja zdravstvenih savjeta i usluga sve većem broju starijih ljudi, kroničnih bolesnika, invalida i drugih psihosocijalno i zdravstveno ugroženih socijalnih skupina. Preusmjeravanjem zdravstvene njege starijih, nemoćnih, kronično bolesnih i invalidnih osoba sa skupih institucionalnih načina zbrinjavanja i skrbi na izvaninstitucionalnu njegu u vlastitom domu, razviti će veliki broj servisa za pomoć, njegu, liječenje i rehabilitaciju u kući u kojima će svojim znanjima i vještinama moći ostvariti važnu ulogu u društvu.

\section{Literatura}

Adler, N. E., Cohen, F., \& Stone, G. C. (1979) Themes and Professional Prospects in Health Psychology. In: Stone, G.C., Cohen, F., \& Adler, N.E. (Eds.). Health Psychology - A Handbook (str. 573-590). San Francisco: Jossey - Bass Publishers.

Arambašić, L. (2008). Gubitak, tugovanje, podrška. Jastrebarsko: Naklada Slap.

Barath, A., Havelka, M. i Selihar, Z. (1987). Društvena podrška i kvaliteta psihosocijalnog prilagođavanja. Radovi Medicinskog fakulteta Sveučilišta u Zagrebu, 28(3), 109 - 118.

Barath, A., Havelka, M. i Gavrilo, P. (1989). Predoperacijska priprema i kvaliteta poslijeoperativnog oporavka kirurških bolesnika: Eksperimentalna studija. Liječnički vjesnik, 111, 116-123.

Barath, A., Havelka, M., Despot Lučanin, J. i Bastašić, Lj. (1990). Psihološka njega i edukacija oboljelih od infarkta miokarda. Radovi Medicinskog fakulteta Sveučilišta u Zagrebu, 31(4), 223-236. 
Barath, A. ( 1995). Kultura, odgoj i zdravlje. Zagreb: Viša medicinska škola.

Barath, A., Matul, D. i Sabljak, Lj. (1996). Korak po korak o oporavka. Zagreb: Tipex.

Becker, M. H. (1974). The health belief model and personal behavior. Health Education Monograph, 2, $324-473$.

Berkman, L.F., \& Breslow, L. (1983). Health and Ways of Life: The Alameda Country Study. Oxford: Oxford University Press.

Bezić, I. (1990). Aspekti kvalitete života pacijenata oboljelih od akutne leukemije - kvalitativna analiza na osnovi psihologijskog rada s pacijentima u sterilnim jedinicama. Bilten $z a$ hematologiju i transfuziju 17(1).

Brajković, L. ( 2012). Kompetencije i uloga psihologa u palijativnoj skrbi. U: Braš, M., Đorđević, V. (ur.), Suvremene spoznaje iz palijativne medicine: Uloga ljekarnika u palijativnoj skrbi (str. 133-139). Zagreb: Medicinska naklada.

Brkljačić, T. i Kaliterna, Lj. (2000). Darivanje tkiva i organa: pomaže li psihologija? U: Manenica, I. (ur.), Zbornik radova XII. Dani psihologije u Zadru. Zadar: Odsjek za psihologiju, Filozofski fakultet u Zadru.

Delegatske informacije (1986). Okvirni obrazovni programi za šesti i sedmi stupanj stručne spreme - znanstvene oblasti: medicinske znanosti. Zagreb: Savez samoupravnih interesnih zajednica usmjerenog obrazovanja SR Hrvatske, Poseban broj 11.

Doll, R., \& Peto, R. (2004). Mortality in relation to smoking: 50 years observations on male British Doctors. British Medical Journal, 328, 15-19.

Galić, S. (2010). Psihološki aspekti tjelesnih bolesti. U: Rumboldt, M., Petrić, D. (ur.), Zbornik radova 17. Kongres Hrvatske udružbe obiteljske medicine (str. 73-75).

Gračanin, A. (2015). Respiratorna sinusna aritmija i emocionalno reagiranje. Psihologijske teme, 24(3), 449-471.

Grgurević, M., Ajduković, D., \& Pibernik- Okanović, M. (2014). Emotional burden of diabetes is comparable among recently diagnosed and previously diagnosed patients. An observation related to the DAWN2 study results. Diabetic medicine, 31(2), 247-248.

Grubić, M. (2008). Psihosocijalni uzroci i posljedice pretilosti u djece. Paediatria Croatica. 52 (Suppl. 1), 57-60.

Grubić, M., Ljubešić, M. i Filipović-Grčić, B. (2013). Kako reći neželjenu vijest. Zagreb: Medicinska naklada.

Havelka, M. i Barath, A. (1977). Sadržaji razgovora liječnika i bolesnika u ordinacijama opće medicine. Liječnički vjesnik broj 98, 649.

Havelka, M., Barath, A. i Novosel, M. (1979). Suvremeni oblici timskog rada u općoj medicini. Kongres međunarodnog udruženja liječnika opće medicine (SIMG), Opatija.

Havelka, M. (1981). Sadržajni aspekti komunikacije kao faktor formiranja odnosa između liječnika i bolesnika. Neobjavljen magistarski rad. Zagreb: Filozofski fakultet Sveučilišta u Zagrebu.

Havelka, M.(1982). Zdravstvena psihologija. Zagreb: Viša medicinska škola Sveučilišta u Zagrebu.

Havelka, M. (1988). Zdravstvena psihologija. Zagreb: Medicinski fakultet Sveučilišta u Zagrebu.

Havelka, M. i Despot Lučanin, J. (1991). Psihologija boli. Zagreb: Medicinski fakultet Sveučilišta u Zagrebu.

Havelka, M. (1998). Zdravstvena psihologija - Udžbenik za srednje zdravstvene škole. Zagreb: Školska knjiga.

Havelka, M. (Ur.). (1998). Zdravstvena psihologija. Jastrebarsko: Naklada Slap. 
Havelka, M., i Ševo, Lj. (2002). Zdravstvena psihologija - Priručnik za nastavnike zdravstvene Psihologije. Zagreb: Školska knjiga.

Havelka, M. (2003). Skrb za starije ljude u Hrvatskoj - potreba uvođenja novih modela. Društvena istraživanja, 12(1/2)(63-64), 225-245.

Havelka, M., Pačić-Turk, Lj. i Sever, T. (2004). Zdravstvena psihologija u Hrvatskoj - dvadesetak godina poslije. Društvena istraživanja, 3(71), 465-486.

Havelka, M. i Havelka Meštrović, A. (2013). Zdravstvena psihologija - Biopsihosocijalne odrednice zdravlja. Zagreb: Zdravstveno veleučilište.

Havelka Meštrović, A. i Čuić, A. (2011). Feeding disorders and modes of upbringing. Klinička psihologija 2-3, 45-49.

Havelka Meštrović, A. i Buhin, L. (2017). Placebo affecting attention - A Smart Pill. RIThink - multidiciplinary online journal RIT Croatia, 6, 22-37.

Havelka Meštrović, A. i Havelka, M. (2018). Zdravstvena psihologija. Jastrebarsko: Naklada Slap.

Havelka, M. i Krizmanić, M. (1995). Psihološka i duhovna pomoć pomagačima. Zagreb: Dobrotvorno udruženje "Dobrobit".

Havelka, M. (1998). Povratak u Hrvatsko podunavlje. Zagreb: Dobrotvorno udruženje "Dobrobit", Hrvatski Caritas, Državni zavod za zaštitu materinstva i mladeži, Visoka zdravstvena škola, Zagreb.

Haynes, R.B., Wang, E., \& DaMota Gomes, M. (1987). A critical review of interventions to improve compliance with prescribed medication. Patient Education and Counseling, $10,155-166$.

HZZO (2013). Odluka o izmjenama $i$ dopunama Odluke o osnovama za sklapanje ugovora o provodenju zdravstvene zaštite iz obveznog zdravstvenog obrazovanja (NN. 128/2013).

Hudek-Knežević, J. i Kardum, I. (2006). Psihosocijalne odrednice tjelesnog zdravlja: I. Stres i tjelesno zdravlje. Jastrebarsko: Naklada Slap.

Hudek-Knežević, J., Kardum, I, i Lesić, R. (1999). Efekti percipiranog stresa i stilova suočavanja na tjelesne simptome. Društvena istraživanja, 8(4), 543-561.

Hudek-Knežević, J. i Kardum, I. (2000). Stres, imunološko funkcioniranje i zdravlje. Psihologijske teme, 8-9(1), 3-28.

Ivanec, D. (2015). Placebo učinak i osjet boli - novija istraživanja. Suvremena psihologija, 18(1), 109-135.

Jokić-Begić, N. i Arambašić, L. (2010). Psihološki čimbenici povezani s genetskim testiranjem. Društvena istraživanja, 19(3), 355-376.

Jokić-Begić, N., Žigić, L., \& Nakić Radoš, S. (2014). Anxiety and anxiety sensitivity as predictors of fear of childbirth: different patterns for nulliparous and parous women. Journal of psychosomatic obstetrics and gynecology, 35(1), 22-28.

Jović, M., Vulić-Prtorić, A., Baraban, D., Grubić, M. Brnović, I., \& Padelin, P. (2009). Coping strategies and health-related quality of life in children and adolescencts with type1 diabetes. Review of psychology, 16(1), 29-36.

Kaliterna, Lj. (1999). Problemi udovištva. Vjesnik Đakovačke i Srijemske biskupije, 77(3), 155-160.

Kostović Srzentić, M., Pukljak Iričanin, Z. Grubić, M., Bogdanić, A., \& Filipović Grčić, B. (2016). Stress Experienced by Parents in The Neonatal Intensive Care Units. U: Lauri Korajlija, A, Begić, D. i Jurin, T. (ur.), 37th STAR Conference "Stress and anxiety in a Changing Society“. Book of Abstracts (str. 129). Zagreb: Medicinska naklada. 
Kostović Srzentić, M., Pukljak Iričanin, Z., Grubić, M., Bogdanić, A., \& Filipović Grčić, B. (2017). Stress experienced by parents in the neonatal intensive care units. Abstract book 31. European Health Psychology Society "Innovative ideas in Health Psychology" (str. 752).

Krizmanić, M., Vizek Vidović, V., Kolesarić, V. i Arambašić, L. (1986). Ispitivanje frekvencije i intenziteta jakih emocionalnih doživljaja u osoba oboljelih od malignih bolesti i zdravih ispitanika. Liječnički vjesnik, 108, 123-126.

Krizmanić, M., Fučkar, G., Havelka, M., Barath, A. i Kolesarić, V. (1991a). Psihološka pomoć u ratu. Zagreb: Katedra za zdravstvenu psihologiju Više medicinske škole Medicinskog fakulteta Sveučilišta u Zagrebu i Odsjek za psihologiju Filozofskog fakulteta Sveučilišta u Zagrebu.

Krizmanić, M., Fučkar, G., Havelka, M., Barath, A. i Kolesarić, V. (1991b). Psihologija i psiholozi u obrani Domovine. Zagreb: Katedra za zdravstvenu psihologiju Više medicinske škole Medicinskog fakulteta Sveučilišta u Zagrebu i Odsjek za psihologiju Filozofskog fakulteta Sveučilišta u Zagrebu.

Krizmanić, M., Fučkar, G., Havelka, M. i Kolesarić, V. (1995). Psihološka pomoć ratnim stradalnicima. Zagreb: Dobrotvorno udruženje "Dobrobit".

Krizmanić, M. (1995). Povratak prognanika. Zagreb: Dobrotvorno udruženje "Dobrobit".

Krizmanić, M., \& Kolesarić, V. (1996). A salutogenic model of psychosocial help. Review of Psychology, 3(1-2), 69-75.

Ljubešić, M. (2013). Interpersonalna komunikacija u zdravstvu. U: Grubić, M., Ljubešić, M., Filipović-Grčić, B. (ur.), Kako reći neželjenu vijest (str. 15-48). Zagreb: Medicinska naklada,

Malčić, I., Carin, R., Jelušić, M., Ivandić, Ž., Aberle, M., \& Grubić, M. (2004). Socioeconomic status and psychosocial behaviour of school children and adolescents with congenital heart disease in Croatia. Cardiology in the Young, 14(suppl 2), 83-83.

Martinac Dorčić, T. i Ljubešić, M. (2009). Psihološka prilagodba roditelja na dijete s kroničnom bolešću. Društvena istraživanja. 18(6), 1107-1129.

Martinac, M., Vrančić, A., Zarevski, P. i Zarevski, Z. (2015). Psihologija za liječnike. Jastrebarsko: Naklada Slap.

Nakić Radoš, S., Tadinac, M., \& Herman, R. (2018). Anxiety during pregnancy and postpartum: Course, predictors and comorbidity with postpartum depression. Acta clinica Croatica, 57(1), 39-51.

Novosel, M. i Havelka, M. (1974). Timovi opće medicine i odnos prema pacijentu. Praxis Medici, 5(1).

Pačić Turk, Lj. (2001). Psihološki čimbenici u liječenju bolesnika s osteoporozom. Zbornik radova II simpozija fizioterapeuta u reumatologiji. Zagreb, (str. 20-23).

Petričić, A. i Vulić Protorić, A. (2009). Some Predictors of Styles of Coping with Diabetes Type 1 and Type 2. Društvena istraživanja 18(1-2), 47-65.

Pibernik-Okanović, M., Szabo, S., \& Metelko, Ž. (1998). Quality of Life Following a Change in Therapy for Diabetes Mellitus. PharmacoEconomics Auckland. 14(2), 201-207.

Pibernik-Okanović, M (2001). Psychometric properties of the World Health Organisation quality of life questionnaire (WHOQOL-100) in diabetic patients in Croatia. Diabetes Research and Clinical Practice, 51(2), 133-143.

Pokrajac-Bulian, A. (2011). Psihološki tretmani pretilosti: Učinkovitost i ograničenja. U: Pokrajac-Bulian (ur.), Pretilost-spremnost za promjenu načina življenja (str. 89-101). Jastrebarsko: Naklada Slap. 
Pukljak Iričanin, Z., Perković, L., Petrak, O., Rukavina M., \& Kostović Srzentić, M. (2011). Coping with pain in patients with osteoarthritis. In: Ajzen, I. (Ed.), 25th Annual Conference of the European Health Psychology Society. Psychology and Health, 26(Supp. 2), 201-202.

Puska, P. (1984). Community-based prevention of cardiovascular disease: The North Karelia Project. In: Matarazzo, J.D., Weiss, S.M., Miller, N.E., \& Herd, J.A. (Eds.), Behavioral Health - A Handbook of Health Enhancement and Disease Prevention (str.1140-1147). New York: John Wiley and Sons.

Rosenstock, I. M. (1974). Historical origins of the health belief model. Health Education, Monographs, 2, 328-35.

Schofield, W. (1969). The role of psychology in the delivery of health services. American Psychologist, 24, 565-584.

Steckler, A., Kenneth, R. McLeroy, \& Holtzman, D. (2010). Godfrey H. Hochbaum (1916-1999). From Social Psychology to Health Behavior and Health Education. American Journal of Public Health, 100(10), 1864.

Sutton, S., Baum, A., \& Johnston, M. (2005). The Sage Handbook of Health Psychology. London: Sage Publications Ltd.

Szabo, S., Pibernik-Okanović, M., \& Metelko, Ž. (2010). Quality of life assessment in the clinical care of diabetes and other chronic diseases: An overview of Croatian experiences. Studia psychologica, 52(2), 147-154.

Tkalčić, M., \& Pokrajac-Bulian, A. (2006). Biopsychosocial aspects of obesity: transtheoretical model of behaviour change. Cognitie, Creier, Comportament/Cognition, Brain, Behavior, 10(1), 53-67.

Tadinac, M. (2004). Biopsihosocijalne odrednice bolesti i zdravlja. U: Žebec, M.S., Sabol, G., Šakić, M. i Kotrla Topić, M. (ur.), Mozak i um - trajni izazov čovjeku (str. 165-173). Zagreb: Institut društvenih znanosti Ivo Pilar.

Tadinac, M., Hromatko, I., Jokić-Begić, N. i Kotrulja, L. (2009). Jastrebovi i grlice: provjera hipoteze darvinijanske medicine na modelu psorijaze. Društvena istraživanja, 18(1-2), 25-45.

Vulić-Prtorić, A. i Galić, S. 2004) Stres i tjelesni simptomi anksioznosti u djece i adolescenata, Medica Jadertina, 34(1-2), 3-13.

Vulić-Prtorić, A., Galić, S. Coha, R. Grubić, M., Lopižić, J., \& Padelin, P. (2007). Anxiety in Children with Headaches. Psychological Topics, 16(2), 201-224.

Zarevski, P., Škrinjarić, I., \& Vranić, A. (2012). Psihologija za stomatologe. Jastrebarsko: Naklada Slap. 